JASEM ISSN 1119-8362

All rights reserved
Full-text Available Online at www.bioline.org.br/ja
J. Appl. Sci. Environ. Manage. September, 2007

Vol. 11(3) $75-79$

\title{
Characterization of Heavy Metals in Vegetables Using Inductive Coupled Plasma Analyzer (ICPA)
}

\section{${ }^{1}$ NIRMAL KUMAR, J I ; ${ }^{2}$ HIREN SONI; ${ }^{3}$ RITA N. KUMAR}

\author{
${ }^{1}$ Department of Environmental Sciences, Institute of Science \& Technology for Advanced Studies \& Research (ISTAR), Vallabh \\ Vidyanagar - 388 120, Gujarat, India \\ ${ }^{2}$ Ashok and Rita Patel Institute of Integrated Study in Biotechnology (ARIIBT), C/o G.J. Patel Ayurveda College, ADIT Campus, GIDC \\ Area, New Vallabh Vidyanagar - 388 121, Gujarat, India \\ ${ }^{3}$ Department of Biosciences \& Environmental Sciences, N.V. Patel College of Pure \& Applied Sciences, Vallabh Vidyanagar - 388 120, \\ Gujarat, India
}

\begin{abstract}
The heavy metals or trace elements play an important role in the metabolic pathways during the growth and development of plants, when available in required concentration. The heavy metal concentration of Cadmium $(\mathrm{Cd})$, Cobalt $(\mathrm{Co})$, Copper $(\mathrm{Cu})$, Iron $(\mathrm{Fe})$, Nickel $(\mathrm{Ni})$, Lead $(\mathrm{Pb})$ and Zinc $(\mathrm{Zn})$ was analyzed using Inductive Coupled Plasma Analyzer (ICPA) (Perkin-Elmer ICP Optima 3300 RL, USA) in 21 vegetables collected from Vegetable Market of Anand town, Gujarat. The vegetables are Lady's Finger (Abelmoschus esculentus), Onion (Alium sepa), Cauliflower (Brassica oleracea var. botrytis), Beat (Brassica oleracea), Chilli (Capsicum annum), Tindora (Coccinia indica), Pattarveli (Colocasia sp.), Coriander (Coriandrum sativum), Cucumber (Cucumis sativus), Turmeric (Curcuma longa), Vetches/Gavar (Cyamopsis soralioides), Bean Pods (Dolichos lablab), Carrot (Ductus carrotus), Ginger (Gingiber officinalis), Sweet Potato (Ipomoea batatas), Bottle Gourd (Lagernaria vulgaris), Tomato (Lycopersicum esculentum), Bitter Gourd (Momordica charantia), Drumstick (Moringa oleifera), Brinjal (Solanum melongena) and Parwar (Trichosanthes dioicea). The high concentration of $\mathrm{Cd}$ was found in Onion, Coriander and Cauliflower, while $\mathrm{Co}$ and $\mathrm{Cu}$ content was recorded high in Cauliflower and Bottle Gourd. On the other hand, high content of Fe was observed in Cauliflower and Cucumber. Vetches and Lady's Finger had shown high concentration of $\mathrm{Ni}$. Cauliflower and Onion showed high amount of $\mathrm{Pb}$. On the other hand, Cucumber and Cauliflower registered maximum content of $\mathrm{Zn}$. The heavy metal concentration in vegetables was within the prescribed safety limits except Fe owing to iron-rich soil of the area. The distribution and characterization of heavy metals in vegetables was studied in detail and discussed in this paper. @JASEM
\end{abstract}

There are 35 metals that concerned us because of occupational or residential exposure; 23 of these are the heavy elements or "heavy metals". Distribution of heavy metals in plant body depends upon availability and concentration of heavy metals as well as particular plant species and its population (Punz and Seighardt 1973).

Many researchers have shown that some common vegetables are capable of accumulating high levels of metals from the soil (Garcia et al. 1981, Khan and Frankland 1983, Xiong 1998, Cobb et al. 2000). Certain species of Brassica (Cabbage) are hyperaccumulators of heavy metals into the edible tissues of plant (Xiong 1998). Many people could be at risk of adverse health effects from consuming common market vegetables cultivated in contaminated soil. Often the condition of the soil is unknown or undocumented; therefore, exposure to toxic levels can occur. $\mathrm{Xu}$ and Thornton (1985) suggested that there are health risks from consuming vegetables with elevated heavy metal concentrations. The populations most affected by heavy metal toxicity are pregnant women or very young children (Boon and Soltanpour 1992). Neurological disorders, CNS destruction, and cancers of various body organs are some of the reported effects of heavy metal poisoning (ATSDR 1994a,b, ATSDR 1999a, ATSDR 1999b, ATSDR 2000). Low birth weight and severe mental retardation of newborn children have been reported in some cases where the pregnant mother ingested toxic amounts of a heavy metal through direct or indirect consumption of vegetables (Mahaffey et al. 1981).

Studies on $\mathrm{Cd}, \mathrm{Cu}$ and $\mathrm{Ni}$ levels in vegetables from industrial and residential areas of Lagos City, Nigeria was carried out by Yusuf et al. (2002) which revealed that the levels of $\mathrm{Cd}, \mathrm{Cu}$ and $\mathrm{Ni}$ in different edible vegetables along with its soils on which they were grown were higher in industrial areas than those of the residential areas due to pollution. Trace element and heavy metal concentrations in fruits and vegetables of the Gediz River region was intensively studied by Delibacak et al. (2002). Also edible portions of five varieties of green vegetables, viz. Amaranth, Chinese Cabbage, Cowpea leaves, Leafy Cabbage and Pumpkin leaves collected from several areas in Dar Es Salaam, Africa, were analyzed for $\mathrm{Pb}$, $\mathrm{Cd}, \mathrm{Cr}, \mathrm{Zn}, \mathrm{Ni}$ and $\mathrm{Cu}$. There was a direct positive correlation between $\mathrm{Zn}$ and $\mathrm{Pb}$ levels in soils with the levels in vegetables. The relation was absent for other heavy metals (Othman et al. 2002). 
In India, similar kind of study was undertaken by Somasundaram et al. (2003) on heavy metal content of plant samples of sewage-irrigated area of Coimbatore district. Leafy vegetables were found with very high levels of heavy metal contamination including $\mathrm{Cd}, \mathrm{Zn}, \mathrm{Cu}, \mathrm{Mn}$ and $\mathrm{Pb}$. A similar research was carried out in Delhi and its surrounding regions on 'Vegetables eating up vegetarians' found the presence of deadly heavy metals in vegetable samples collected from across the capital (The Hindu 2003).

Rana and Nirmal Kumar (1988) and Nirmal Kumar et al. (1989) have investigated elemental composition of certain aquatic plants by Energy Dispersive X-Ray Analysis (EDAX). Heavy metals like Al, Si, Mn, Fe were found accumulated in Vallisnaria spiralis, Hydrilla verticillata and Azolla pinnata. Nirmal Kumar and Rita N. Kumar (1997) also carried out elemental composition of certain economic important plants by EDAX. Some studies on distribution and characterization of heavy metals in vegetable plants and its parts collected from organic farms and village agriculture fields around Anand province, Gujarat, was also carried out by Nirmal Kumar et al. (2004). The present investigation aims to study the distribution and characterization of heavy metals in common vegetables sold in vegetable market of Anand town, Milk City of Asia, Gujarat.

\section{MATERIALS AND METHODS}

In the present study, 21 fresh vegetables sold in vegetable market of Anand town, Gujarat were collected and brought to the laboratory. The common vegetables available in market are Bean Pods, Beet, Bitter Gourd, Bottle Gourd, Brinjal, Carrot, Cauliflower, Coriander, Cucumber, Drumstick, Gavar, Tindora, Ginger, Chilli, Lady's Finger, Onion, Parwar, Pattarveli, Sweet Potato, Tomato and Turmeric. The edible parts of these vegetables like roots, stems, leaves, flowers and fruits were collected.

The samples were brought to the laboratory and washed under tape-water gently. The moisture and water droplets were removed with the help of blotting papers. $0.5 \mathrm{gm}$ dry powder was weighed by electric monopan balance (Dhona 200D) and digested with Sulphuric acid $\left(\mathrm{H}_{2} \mathrm{SO}_{4}\right)$, Nitric acid $\left(\mathrm{HNO}_{3}\right)$ and Hydrogen Peroxide $\left(\mathrm{H}_{2} \mathrm{O}_{2}\right)$ (2:6:6) as prescribed by Saison et al. (2004). The samples were analyzed in Inductive Coupled Plasma Analyzer (ICPA) (PerkinElmer ICP Optima 3300 Rl, USA) at Sophisticated Instrumentation Center for Applied Research and Testing (SICART), Vallabh Vidyanagar, Gujarat. The concentration of heavy metals such as Cadmium
$(\mathrm{Cd})$, Cobalt $(\mathrm{Co})$, Copper $(\mathrm{Cu})$, Iron $(\mathrm{Fe})$, Nickel $(\mathrm{Ni})$, Lead $(\mathrm{Pb})$ and Zinc $(\mathrm{Zn})$ were analyzed. The reading of each sample is calculated by taking the average readings of duplicate sets. All values are mentioned in $\mathrm{mg} / \mathrm{gr}$ dry weight.

\section{RESULTS}

Table 1 shows the concentration spectra of various heavy metals such as Cadmium (Cd), Cobalt (Co), Copper $(\mathrm{Cu})$, Iron $(\mathrm{Fe})$, Nickel $(\mathrm{Ni})$, Lead $(\mathrm{Pb})$ and Zinc $(\mathrm{Zn})$ in different vegetables. In the present investigation, the value of Cadmium $(\mathrm{Cd})$ ranges from 0.002 to $0.029 \mathrm{mg} / \mathrm{gr}$ in various vegetables. The maximum concentration $(0.029 \mathrm{mg} / \mathrm{gr})$ of $\mathrm{Cd}$ was recorded in reduced stem of Onion, while minimum concentration $(0.002 \mathrm{mg} / \mathrm{gr})$ was registered in fruits of Gavar. Acute doses (10-30 mg/kg/day) of Cadmium can cause severe gastrointestinal irritation, vomiting, diarrhea, and excessive salivation, and doses of $25 \mathrm{mg}$ of $\mathrm{Cd} / \mathrm{kg}$ body weight can cause death. Low-level chronic exposure to $\mathrm{Cd}$ can cause adverse health effects including gastrointestinal, hematological, musculoskeletal, renal, neurological, and reproductive effects. The main target organ for $\mathrm{Cd}$ following chronic oral exposure is the kidney (ATSDR 1999a). Intake of Cd can double if one smokes cigarettes because each cigarette contains about $2 \mathrm{mg} \mathrm{Cd}$.

The Cobalt (Co) content varies from 0.002 to 0.319 $\mathrm{mg} / \mathrm{gr}$. The lowest concentration $0.002 \mathrm{mg} / \mathrm{gr}$ of Co was observed in fruits of Turmeric. On the other hand, Cauliflower showed highest concentration of Co $(0.319 \mathrm{mg} / \mathrm{gr})$. Deficiency of Co in diet results into pernicious anemia, severe fatigue, shortness of breath and hypothyroidism, while overdose may lead to angina, asthma, cardiomyopathy, polycythemia and dermatitis. The safety limit for human consumption of Co is 0.05 to $1 \mathrm{mg}$ /day in humans (ATSDR 1994a). Thus the recorded range of Cobalt concentration in vegetables falls within the safety limit during present investigation.

The acceptable limit for human consumption of Copper $(\mathrm{Cu})$ is 10 ppm (Nair et al. 1997). When $\mathrm{Cu}$ exceeds its safe level concentration, it causes hypertension, sporadic fever, uremias, coma etc. Present investigation reveals that $\mathrm{Cu}$ varies from 0.123 to $2.308 \mathrm{mg} / \mathrm{gr}$, which falls below the safe limits for human health and hygiene. The highest concentration of $\mathrm{Cu}$ was found in Cauliflower (2.308 $\mathrm{mg} / \mathrm{gr}$ ), while lowest concentration $0.123 \mathrm{mg} / \mathrm{gr}$ was recorded in fruits of Parwar. As it falls within safety limits $(10 \mathrm{ppm})$, the vegetables, which contain $\mathrm{Cu}$, can be used for an edible purpose without any risk. 
Table 1: shows concentration of heavy metals of selected vegetables collected from Anand Vegetable Market (mg/gr dry weight)

\begin{tabular}{|c|c|c|c|c|c|c|c|c|c|c|}
\hline \multirow{2}{*}{\multicolumn{2}{|c|}{ Sr. No. Botanical Name }} & \multirow{3}{*}{$\begin{array}{l}\text { Common Name } \\
\text { Lady's Finger }\end{array}$} & \multirow{3}{*}{$\begin{array}{l}\begin{array}{l}\text { Plant } \\
\text { Part }\end{array} \\
\text { Fruit }\end{array}$} & \multicolumn{7}{|c|}{ Heavy metals } \\
\hline & & & & \multirow{2}{*}{$\begin{array}{l}\mathrm{Cd} \\
0.005\end{array}$} & \multirow{2}{*}{$\begin{array}{l}\text { Co } \\
0.009\end{array}$} & \multirow{2}{*}{$\begin{array}{l}\mathrm{Cu} \\
0.165\end{array}$} & \multirow{2}{*}{$\begin{array}{l}\mathrm{Fe} \\
13.661\end{array}$} & \multirow{2}{*}{$\begin{array}{l}\mathrm{Ni} \\
3.034\end{array}$} & \multirow{2}{*}{$\begin{array}{l}\mathrm{Pb} \\
0.066\end{array}$} & \multirow{2}{*}{$\begin{array}{l}\mathrm{Zn} \\
3.283\end{array}$} \\
\hline 1 & Abelmoschus esculentus & & & & & & & & & \\
\hline \multirow[t]{3}{*}{2} & Alium sepa & Onion & Stem & 0.029 & 0.016 & 0.832 & 39.980 & 0.742 & 0.280 & 4.265 \\
\hline & & & Leaf & 0.008 & 0.009 & 0.781 & 14.972 & 1.365 & 0.236 & 3.637 \\
\hline & & & Bulb & 0.009 & 0.003 & 0.365 & 11.598 & 2.031 & 0.143 & 4.613 \\
\hline 3 & Brassica oleracea & Beet & Root & 0.005 & 0.020 & 0.323 & 18.744 & 0.501 & 0.149 & 3.321 \\
\hline 4 & $\begin{array}{l}\text { Brassica oleracea var. } \\
\text { botrytis }\end{array}$ & Cauliflower & Flower & 0.018 & 0.319 & 2.308 & 131.225 & 0.944 & 0.256 & 8.992 \\
\hline 5 & Capsicum аппит & Chilli & Fruit & 0.007 & 0.011 & 0.838 & 9.537 & 2.032 & 0.073 & 2.773 \\
\hline 6 & Coccinia indica & Tindora & Fruit & 0.009 & 0.007 & 0.533 & 8.548 & 2.569 & 0.131 & 3.680 \\
\hline 7 & Colocasia sp. & Pattarveli & Root & 0.009 & 0.059 & 0.288 & 15.368 & 1.446 & 0.160 & 2.458 \\
\hline \multirow[t]{2}{*}{8} & Coriandrum sativum & Coriander & Root & 0.008 & 0.018 & 0.768 & 16.972 & 0.417 & 0.137 & 2.541 \\
\hline & & & Stem & 0.018 & 0.041 & 1.156 & 19.061 & 0.474 & 0.152 & 3.927 \\
\hline 9 & Cucumis sativus & Cucumber & Fruit & 0.010 & 0.030 & 0.592 & 24.130 & 2.151 & 0.122 & 12.676 \\
\hline 10 & Curcuma longa & Turmeric & Stem & 0.007 & 0.002 & 0.208 & 10.445 & 0.442 & 0.094 & 2.373 \\
\hline 11 & Cyamopsis soralioides & $\begin{array}{l}\text { Gavar } \\
\text { (Vetches) }\end{array}$ & Fruit & 0.002 & 0.005 & 0.240 & 6.337 & 4.493 & 0.103 & 3.707 \\
\hline 12 & Dolichos lablab & Bean Pods & Fruit & 0.007 & 0.011 & 0.838 & 9.537 & 2.032 & 0.073 & 2.773 \\
\hline 13 & Ductus carrotus & Carrot & Root & 0.006 & 0.011 & 0.573 & 13.043 & 0.345 & 0.078 & 2.155 \\
\hline 14 & Gingiber officinalis & Ginger & Stem & 0.006 & 0.015 & 0.502 & 14.524 & 0.392 & 0.019 & 3.574 \\
\hline 15 & Ipomoea batatas & Sweet Potato & Root & 0.006 & 0.026 & 0.601 & 6.559 & 0.344 & 0.034 & 1.655 \\
\hline 16 & Lagernaria vulgaris & Bottle Gourd & Fruit & 0.016 & 0.065 & 0.971 & 13.421 & 0.906 & 0.170 & 3.125 \\
\hline 17 & Lycopersicum esculentum & Tomato & Fruit & 0.012 & 0.018 & 0.560 & 11.564 & 1.259 & 0.059 & 3.278 \\
\hline 18 & Momordica charantia & Bitter Gourd & Fruit & 0.008 & 0.005 & 0.270 & 11.327 & 0.221 & 0.136 & 2.740 \\
\hline 19 & Moringa oleifera & Drumstick & Fruit & 0.011 & 0.003 & 0.567 & 7.422 & 1.643 & 0.111 & 3.305 \\
\hline 20 & Solanum melongena & Brinjal & Fruit & 0.008 & 0.008 & 0.728 & 9.541 & 2.222 & 0.111 & 3.065 \\
\hline 21 & Trichosanthes dioicea & Parwar & Fruit & 0.005 & 0.009 & 0.123 & 6.923 & 0.125 & 0.083 & 3.535 \\
\hline
\end{tabular}

Iron is an essential element in production of Red Blood Cells (RBCs). The concentration of Iron (Fe) content was highest in Cauliflower $(131.225 \mathrm{mg} / \mathrm{gr})$, while it was found lowest $(6.337 \mathrm{mg} / \mathrm{gr})$ in fruits of Gavar. The Fe content ranges from 6.337 to 131.225 $\mathrm{mg} / \mathrm{gr}$. Low intake of Fe may cause anemia, tiredness and pallid physique, while high intake may results into hepatic megaly, cardiac infraction and nephric malfunction. The acceptable limit for human consumption of Iron is 8 to $11 \mathrm{mg} /$ day for infants as well as adults (ATSDR 1994b). During present investigation, the value of $\mathrm{Fe}$ was found much higher, which is significant due to iron-rich soil of the area.

Nickel is found in soybeans, lentils, nuts, grains and vegetables. Fruits of Gavar showed high content of Nickel $(4.493 \mathrm{mg} / \mathrm{gr})$, while fruits of Parwar contain low value of $\mathrm{Ni}(0.125 \mathrm{mg} / \mathrm{gr})$. The presence of $\mathrm{Ni}$ ranges from 0.125 to $4.493 \mathrm{mg} / \mathrm{gr}$ in various vegetables.

Deficiency of Nickel have been linked with hyperglycemia, depression, sinus congestion, fatigue, reproductive failures and growth problems in humans, while excess intake leads to hypoglycemia, asthma, nausea, headache, and epidemiological symptoms like cancer of nasal cavity and lungs. The prescribed safety limit of Nickel is 3 to $7 \mathrm{mg}$ /day in humans (ATSDR 1999a). Thus it falls within the safety limit in vegetables and can be consumed without any risk.

During the present study, Lead $(\mathrm{Pb})$ content varies from 0.019 to $0.280 \mathrm{mg} / \mathrm{gr}$, which falls within safety limit (1.5 ppm) for human consumption (Nair et al. 1997). $\mathrm{Pb}$ content was found high in Cauliflower $(0.256 \mathrm{mg} / \mathrm{gr})$, while stem of Ginger showed low concentration of $\mathrm{Pb}(0.019 \mathrm{mg} / \mathrm{gr})$. Todd (1996) emphasized that most of the accumulated Lead is sequestered in the bones and teeth. This causes brittle bones and weakness in the wrists and fingers. Lead that is stored in bones can reenter the blood stream during periods of increased bone mineral recycling (i.e., pregnancy, lactation, menopause, advancing age, etc.). Mobilized lead can be redeposited in the soft tissues of the body and can cause 
musculoskeletal, renal, ocular, immunological, neurological, reproductive, and developmental effects (ATSDR 1999b).

Among all metals, Zinc ( $\mathrm{Zn})$ is the least toxic and an essential element in the human diet as it is required to maintain the proper functions of the immune system. It is also important for normal brain activity and is fundamental in the growth and development of the foetus. Zinc deficiency in the diet may be more detrimental to human health than too much Zinc in the diet. Although the average daily intake of Zinc is 7-16.3 $\mathrm{mg} \mathrm{Zn} /$ day, the recommended dietary allowance for it is $15 \mathrm{mg} \mathrm{Zn}$ /day for men and $12 \mathrm{mg}$ $\mathrm{Zn}$ /day for women (ATSDR 1994a). On the contrary, the high concentration of Zinc in vegetables may cause vomiting, renal damage, cramps etc.

The acceptable limit for human consumption of $\mathrm{Zn}$ is $150 \mathrm{ppm}$ (Nair et al. 1997). During present study, the concentration of $\mathrm{Zn}$ was found high in fruits of Cucumber (12.686 mg/gr), while low concentration of $\mathrm{Zn}$ was observed in fruits of Sweet Potato (1.655 $\mathrm{mg} / \mathrm{gr})$. The content of $\mathrm{Zn}$ ranges from 1.655 to $12.676 \mathrm{mg} / \mathrm{gr}$, which falls within the safe limit. Thus the trend of concentration of various heavy metals in studied vegetables is as follows: $\mathrm{Fe}>\mathrm{Zn}>\mathrm{Ni}>\mathrm{Cu}>$ $\mathrm{Pb}>\mathrm{Co}>\mathrm{Cd}$

Acknowledgement: Authors are thankful to "Charotar Ratna" and "Shalin Manav Ratna" Dr. C.L. Patel, Chairman, Charutar Vidya Mandal (CVM), Vallabh Vidyanagar, for being a constant source of inspiration, initiation and motivation to carry out this piece of work and permitted us to utilize Inductive Coupled Plasma Analyzer (ICPA) at Sophisticated Instrumentation Center for Applied Research and Testing (SICART), Vallabh Vidyanagar, Gujarat.

\section{REFERENCES}

Agency for Toxic Substances and Disease Registry (ATSDR). 1994a. Toxicological Profile for Zinc and Cobalt. US Department of Health and Human Services, Public Health Service. 205-880608 .

Agency for Toxic Substances and Disease Registry (ATSDR). 1994b. Toxicological Profile for Nickel and Iron. Agency for Toxic Substances and Disease Registry, US Department of Health and Human Services, Public Health Service. 205-88-0608.

Agency for Toxic Substances and Disease Registry (ATSDR). 1999a. Toxicological Profile for Cadmium and Nickel. Agency for Toxic Substances and Disease Registry, US

NIRMAL KUMAR, J I; HIREN SONI; RITA N. KUMAR
Department of Health and Human Services, Public Health Service. 205-93-0606.

Agency for Toxic Substances and Disease Registry (ATSDR). 1999b. Toxicological Profile for Lead. Agency for Toxic Substances and Disease Registry, US Department of Health and Human Services, Public Health Service. 205-93-0606.

Agency for Toxic Substances and Disease Registry (ATSDR). 2000. Toxicological Profile for Arsenic. Agency for Toxic Substances and Disease Registry, US Department of Health and Human Services, Public Health Service. 2051999-00024.

Boon, D.Y. and Soltanpour, P.N. 1992. Lead, Cadmium, and Zinc Contamination of Aspen Garden Soils and Vegetation. Journal of Environmental Quality. 21: 82-86.

Bunzl, K., Trautmannsheimer, M., Schramel, P. and Reifenhäuser, W. 2001. Availability of Arsenic, Copper, Lead, Thallium, and Zinc to Various Vegetables Grown in Slag-Contaminated Soils. Journal of Environmental Quality. 30: 934-939.

Cobb, G.P., Sands, K., Waters, M., Wixson B.G. and Dorward-King, E. 2000. Accumulation of Heavy Metals by garden vegetables. Journal of Environmental Quality. 29: 934-939.

Delibacak, S., Elmaci, O.L, Secer, M. and Bodur, A. 2002. Trace element and heavy metal concentrations in fruits and vegetables of the Gediz River region. International Journal of Water. Vol. 2, No. 2/3.

Garcia, W.J., Blessin, C.W., Inglett, G.E. and Kwolek, W.F. 1981. Metal Accumulation and Crop Yield for a Variety of Edible Crops Grown in Diverse Soil Media Amended with Sewage Sludge. Environmental Science and Technology. 15 (7): 793-804.

Khan, D.H. and Frankland, B. 1983. Effects of cadmium and lead on radish plants with particular reference to movement of metals through soil profile and plant. Plant and Soil. 70: 335-345.

Mahaffey, K.R, Capar, S.G., Gladen, B.C. and Fowler, B.A. 1981. Concurrent exposure to lead, cadmium, and arsenic. Effects on toxicity and tissue metal concentrations in the rat. Journal of Laboratory and Clinical Medicine. 98 (4): 46381. 
Nair, M., Balachandran, K.K. Sankarnarayan, V.N. and Joseph, T. 1997. Heavy metals in fishes from coastal waters of Cochin, South West Coast of India. Indian Journal of Marine Science. 26: 98-100.

Nirmal Kumar, J.I., Sreenivas, S.S and Rana, B.C. 1989. EDAX- analysis of mud of four ponds from Central Gujarat. Indian Botanical Contractor. 6: 75-76.

Nirmal Kumar, J.I. and Kumar, R.N. 1997. Elemental composition of certain economic important plants by EDAX. Proceedings of National Symposium on Plant Morphogenesis. pp.177181.

Nirmal Kumar, J.I., Rita N. Kumar, Hiren Soni and Ira Bhatt. 2004. Distribution and Characterization of Heavy Metals of Vegetable Plants in and around Anand, Gujarat. Technical Report submitted to Charutar Vidya Mandal (CVM), Vallabh Vidyanagar, Gujarat, India. 139 pp.

Othman, O.C. 2001. Heavy metals in green vegetables and soils from vegetable gardens in Dar Es Salaam, Tanzania. Tanzania Journal of Science. 27: 37-48.

Punz, W.F. and Sieghardt, H. 1993. The response of roots of herbaceous plant species to heavy metals. Environment and Experimental Botany, 33 (1): 85-98.
Rana, B.C and Nirmal Kumar, J.I. 1988. Energy Dispersal Analysis of X-rays of certain aquatic macrophytes. Indian Journal of Weed Science. 20: 46-49.

Saison, C., Schwartz, C. and Morel, J.L. (2004). Hyperaccumulation of metals by Thlaspi caerulescens as affected by root development and $\mathrm{Cd}-\mathrm{Zn} / \mathrm{Ca}-\mathrm{Mg}$ interactions. International Journal of Phytoremediation. 6 (1): 49-61.

Somasundaram, J. 2003. Imbibing toxic/heavy metals through leafy vegetables. In: The Hindu. Online edition of India's National Newspaper. 6th November. The Hindu. 2003. Vegetables eating up vegetarians. The Hindu. 27 $7^{\text {th }}$ March. New Delhi.

Todd, G.C. 1996. Vegetables Grown in Mine Wastes. Environmental Toxicology and Chemistry. 19 (3): 600-607.

Xiong, Z.T. 1998. Lead Uptake and Effects on Seed Germination and Plant Growth in a $\mathrm{Pb}$ Hyperaccumulator Brassica pekinensis Rupr. Bulletin of Environmental Contamination and Toxicology. 60: 285-291.

$\mathrm{Xu}, \mathrm{J}$. and Thornton, I. 1985. Arsenic in garden soils and vegetable crops in Cornwall, England: implications for human health. Environmental Geochemistry and Health. 7(4): 131-133.

Yusuf, A.A., Arowolo, T.O.A. and Bamgbose, O. 2002. Cadmium, copper and nickel levels in vegetables from industrial and residential areas of Lagos City, Nigeria. Global Journal of Environmental Science. Vol.1 (1): 1-6. 